\title{
Small-Scale Fermentation of Cocoa Beans and the Parameter for on-Process Monitoring
}

\author{
Ariza Budi Tunjung Sari ${ }^{\left.{ }^{*}\right)}$, Hendy Firmanto ${ }^{1)}$, and Teguh Wahyudi ${ }^{1)}$ \\ ${ }^{1)}$ Indonesian Coffee and Cocoa Research Institute, Jl. PB Sudirman 90, Jember 68118, East Java, Indonesia \\ ${ }^{*}$ Corresponding author: ariza.bts@gmail.com \\ Received: 5 October 2020 / Accepted: 18 February 2021
}

\begin{abstract}
Cocoa bean fermentation is a critical step in the formation of chocolate aroma precursors. Small-scale fermentation is needed to accommodate fermentation practice during low season and fruit scarcity. The study was conducted to address the minimum amount of wet cocoa beans required for a successful fermentation. In the trials, wet cocoa beans at different quantities, i.e. 1, 2.5, 5, 7.5, 10, 15 , and $40 \mathrm{~kg}$, were incubated in separate wooden boxes for 4 days (96 hours) and turned once after 48 hours. Temperature and $\mathrm{pH}$ of the pulp and beans were measured every 6 hours. Dry beans were visually inspected to determine the number of grayish and purple cotyledons indicating unfermented beans. In general, smaller scale fermentations, i.e. 1 to $15 \mathrm{~kg}$, resulted in similar profiles with that of standard mini-box fermentation $(40 \mathrm{~kg}$ ) in terms of temperature, pulp $\mathrm{pH}$ and bean $\mathrm{pH}$. The $40 \mathrm{~kg}$ fermentation resulted in the lowest percentage of purple beans with no grayish beans, meanwhile smaller scale fermentations showed higher number of unfermented beans. The logarithmic regression indicates that as much as $1.4 \mathrm{~kg}$ beans my producing unfermented beans of less than $20 \%$ which meets the criteria of grade 3 based on the Indonesian National Standard for cocoa bean (SNI 2323:2008/Amd1:2010). Data analysis shows that temperature below $35^{\circ} \mathrm{C}$ for 42 hours was associated with higher percentage of grayish and purple beans. It is concluded that cocoa bean fermentation can be carried out at least at $5 \mathrm{~kg}$ scale, and temperature at 42 hours could be a parameter for process monitoring.
\end{abstract}

Keywords: cocoa, fermentation, quality, small-scale, smallholder

\section{INTRODUCTION}

Cocoa, as the main ingredient of chocolate, has continuously been growing in the context of global demand. World consumption is estimated to increase of up to $30 \%$ by 2020 (Beg et al., 2017). Indonesia, as one of major cocoa producing countries, is notorious for low quality beans due to high number of unfermented beans and waste, particularly those from smallholder farms (Neilson, 2007). There are several reasons underlying the non-fermentation practice of smallholder farmers in Indonesia. A survey conducted by Raharto (2019) revealed that the main factor is the unappealing price difference between unfermented and the fermented beans. Another factor is farmers' perception on complicated process of fermentation and uncertain quality of the products.

The quantity of wet beans is important for a successful fermentation. The typical quantity for fermentation is around $200-1000 \mathrm{~kg}$ of wet beans (Ardhana \& Fleet, 2003; Camu et al., 2008; Fahrurrozi et al., 2015). A shallow box fermentation had also been introduced, involving $150 \mathrm{~kg}$ of wet beans (Sulaiman $\&$ Yang, 2015). Furthermore, protocols for smaller scale fermentation, i.e. $40 \mathrm{~kg}$ (Pereira 
et al., 2013) and $20 \mathrm{~kg}$ (Lefeber et al., 2011) had been introduced.

However, the adequate quantity for a proper cocoa bean fermentation in Indonesia has been challenging. Indonesian cocoa beans are mostly produced by smallholder farmers with average farm size that is less than two hectares with dry bean production is merely $350 \mathrm{~kg} \cdot$ ha $^{-1}$.year ${ }^{-1}$ (Tothmihaly et al., 2017). In certain months, the production of wet cocoa beans in a farm will plummet into less than $10 \mathrm{~kg}$ per harvesting period (Santosa et al., 2018). High variation in the quantity wet beans a protocol for handling for lower amount cocoa beans. In addition, to determine a successful fermentation, an on-process monitoring indicator should be established.

In this study, cocoa fermentations were conducted using several different quantities of wet beans. In the standard protocol of fermentation, minimum quantity of wet beans at $40 \mathrm{~kg}$ with $40 \mathrm{~cm}$ of depth is recommended (Yusianto, 1990). The objective of this study was to assign the lowest possible quantity that allows minimum quality of cocoa beans based on Indonesian National Standard, SNI 2323:2008/Amd1:2010 (BSN, 2010). The onprocess monitoring indicator was established by means of correlational analysis between fermentation temperature and the percentage of grayish and purple beans.

\section{MATERIALS AND METHODS}

\section{Cocoa Bean Preparation and Fermentation}

The trial applied completely randomized design, with a single factor, i.e. seven level of box capacities applying three replications, resulting 21 experimental units. Cocoa pods were obtained from Kaliwining Experimental Station of ICCRI located in Jember. Pods were manually opened and beans were collected. Beans were stirred for homogenization before being distributed to separate wooden boxes at quantities $1,2.5,5,7.5,10,15$, and $40 \mathrm{~kg}$. Fermentation box has a fixed width, and the length was adjusted with partitioning board from the same wood material, to maintain the depth of the beans not less than $40 \mathrm{~cm}$ (Yusianto, 1990). Beans were covered with jute sheets and being fermented for 96 hours with turning once after 48 hours. In the end of fermentation, beans were sun-dried on a tarp sheet and the moisture content was measured every day using a digital moisture tester. The drying was stopped when moisture content reached $7 \%$, and the beans were stored at room temperature.

\section{Observation and Analysis}

Throughout fermentation, temperature and $\mathrm{pH}$ of the pulp were measured every six hours by probing thermometer and $\mathrm{pH}$-meter into the fermenting mass, at depth $\pm 15 \mathrm{~cm}$ from the surface to reach center point inside the mass. At every time point, five beans were taken out, cleaned from the testa, pounded and added with $50 \mathrm{~mL}$ of distilled water to measure the $\mathrm{pH}$ of cotyledon. Dried beans after fermentation were cut length wise to assess the physical quality including the percentage of grayish, fully purple, and partly purple beans. The result was then evaluated according to Indonesian National Standard for cocoa beans, SNI 2323:2008/Amd1:2010 (BSN, 2010).

\section{Statistical Analysis}

Data from observation and physical quality analysis were collected. The mean and standard deviation values were calculated from three replications. The data were tested for Shapiro-Wilk's normality and Levene's homogeneity. Data which passed the tests were proceeded to one-way Analysis of Variance and Tukey's HSD post-hoc test. 
Data that did not pass the tests were proceeded to a non-parametric Kruskal-Wallis test. Correlational analysis was done to evaluate the relationship between observational data (temperature and $\mathrm{pH}$ during fermentation) and physical quality (slaty and grayish bean numbers). A regression was performed on the bean weight against the number of unfermented beans to determine the lowest possible fermentation scale that allows inclusion in the criteria of SNI 2323:2008/Amd1:2010 (BSN, 2010).

\section{RESULTS AND DISCUSSION}

Fermentation is a simple yet crucial step in cocoa bean processing. This step enables the development of aroma precursors and at the same time, eliminating of bitterness and astringency. The fermentation consists of two phases, i.e. anaerobic and aerobic phases. Anaerobic phase is mostly occupied by yeasts and lactic acid bacteria. The yeast breaks down carbohydrate in the pulp resulting in the glucose, fructose and ethanol. Lactic acid bacteria then utilize yeast degradation products to yield lactic acid, acetic acid, ethanol and mannitol. Aerobic phase is commenced by turning during which oxygen is introduced. In the aerobic condition, acetic acid bacteria convert ethanol into acetic acid (de Vuyst \& Leroy, 2020). The lactic acid produced in the anaerobic phase is utilized by acetic acid bacteria for growth (Pelicaen et al., 2019).

\section{Temperature and $\mathrm{pH}$}

The temperature profile of cocoa bean fermentation typically increases over the course of fermentation, as a consequence of growth and metabolism of the microorganism in the pulp (Lefeber et al., 2011; Pereira et al., 2013; Fahrurrozi, 2015). Ascending temperature profile was demonstrated in the fermentations at 7.5, 10,15 and $40 \mathrm{~kg}$, whose temperature increased at 48 and 96 hours. On the other hand, temperature in the fermentation at $1-5 \mathrm{~kg}$ rose only in the first 48 hours, then declined after turning to final temperature higher than the initial state (Figure 1). This suggests slower metabolism of acetic acid bacteria due to insufficient substrates given low amount of pulp in the fermenting mass (Pelicaen et al., 2019; de Vuyst \& Leroy, 2020).

There was rapid increase at 24 hours temperature in the $40 \mathrm{~kg}$-fermentation, potentially triggered by aggressive yeast metabolism towards abundant pulp. Similarly, this is also occurred in the $5 \mathrm{~kg}$ fermentation. Yeast metabolism might have been accommodated at $5 \mathrm{~kg}$ scale, considering the availability of pulp compared with 1 and $2.5 \mathrm{~kg}$ fermentations. However, a rapid 24 hours temperature increase was not observed in the 7.5, 10, and $15 \mathrm{~kg}$ fermentations. In the anaerobic phase, the fermenting mass becomes less dense as the pulp leaches. In the $5 \mathrm{~kg}$

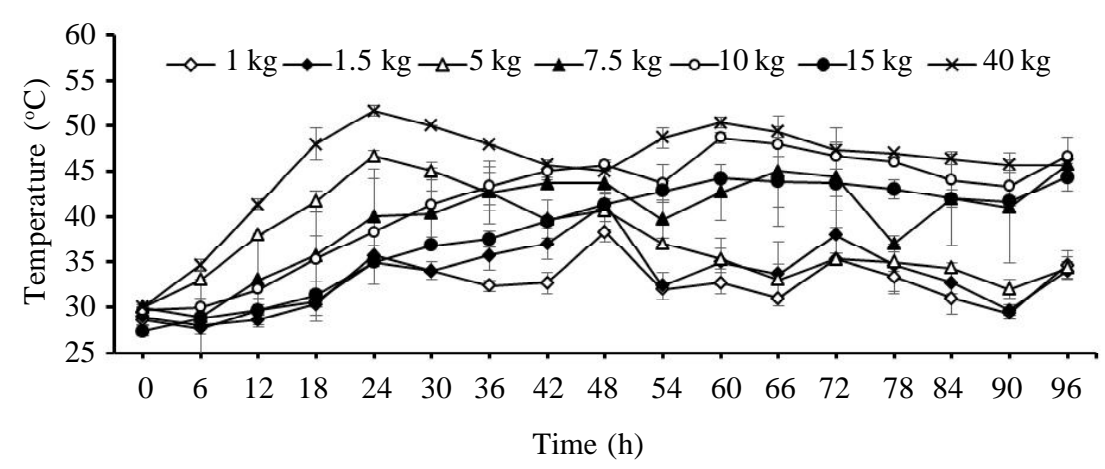

Figure 1. Temperature profile of cocoa fermenting mass at several different scales; $1 \mathrm{~kg}, 2.5 \mathrm{~kg}, 5 \mathrm{~kg}, 7.5 \mathrm{~kg}$, $10 \mathrm{~kg}, 15 \mathrm{~kg}$, and $40 \mathrm{~kg}$ as the control treatment. Data are means of three replications 
fermentation, the density might have been lower than fermentation at higher scales. This allows some oxygen to enter the fermenting mass and enhance the metabolism of some type of yeasts. Saccharomyces cerevisiae had been reported to have better metabolism in slightly aerated condition (Deesuth et al., 2016).

Pulp pH gradually increased throughout fermentation (Figure 2). The source of acidity in the initial stage of fermentation is citric acid in the pulp. As pulp is degraded by yeast, it leaches and loses the citric acid. Additionally, organic acids produced by lactic acid and acetic acid bacteria diffuse into the interior part of the beans, inducing lower $\mathrm{pH}$ in the cotyledon and leaving pulp at higher $\mathrm{pH}$ (Ardhana \& Fleet, 2003; Camu et al., 2008). All treatments showed rising $\mathrm{pH}$ of the pulp indicating the successful pulp degradation and acid loss.

In the other hand, cotyledon $\mathrm{pH}$ decreased as fermentation progressed (Figure 3), confirming the acid transfer from pulp to cotyledon. In all treatments, rapid decreases occurred in the first 42 hours and slight increases were observed afterwards. The final $\mathrm{pH}$ was averagely $0.97-2$ points lower than initial $\mathrm{pH}$. The acidity of bean is critical for development of amino acids as precursors for chocolate aroma. Inside the beans, lower $\mathrm{pH}$ is important for activity of aspartic endoprotease that breaks down protein into peptides, then a slightly higher $\mathrm{pH}$ is needed for carboxypep-

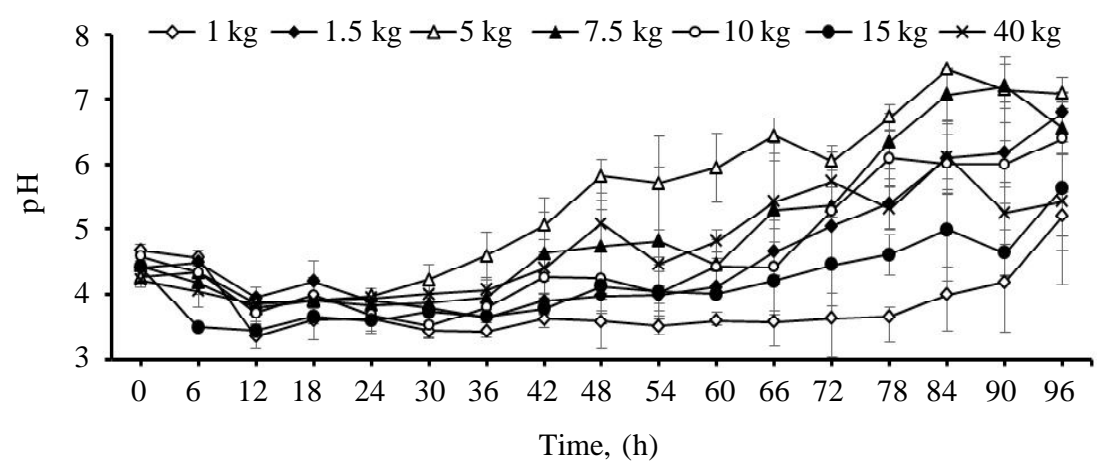

Figure 2. Acidity $(\mathrm{pH})$ profile of cocoa pulp during fermentation at several different scales; $1 \mathrm{~kg}, 2.5 \mathrm{~kg}$, $5 \mathrm{~kg}, 7.5 \mathrm{~kg}, 10 \mathrm{~kg}, 15 \mathrm{~kg}$, and $40 \mathrm{~kg}$ as the control treatment; Data are means of three replications

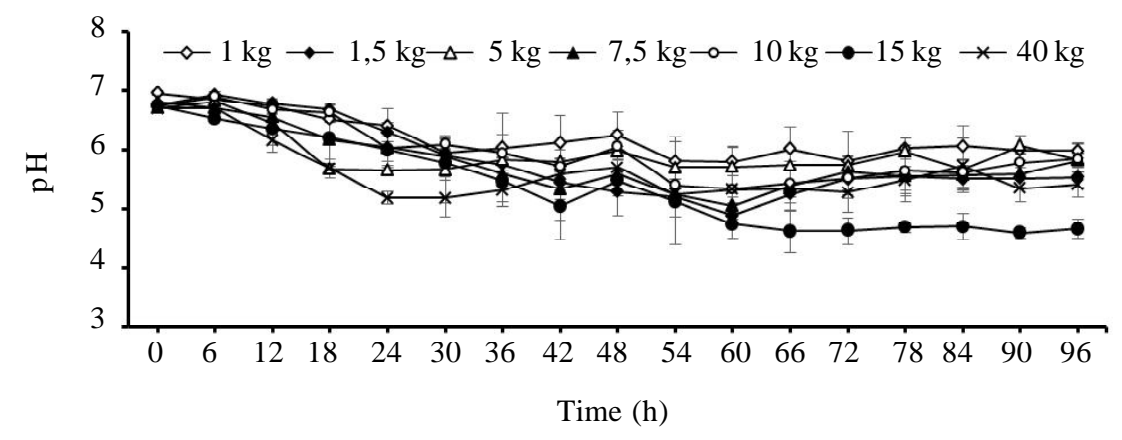

Figure 3. Acidity $(\mathrm{pH})$ profile of cocoa cotyledons during fermentation at several different scales; $1 \mathrm{~kg}$, $2.5 \mathrm{~kg}, 5 \mathrm{~kg}, 7.5 \mathrm{~kg}, 10 \mathrm{~kg}, 15 \mathrm{~kg}$, and $40 \mathrm{~kg}$ as the control treatment; Data are means of three replications 
tidase activity to break peptides into hydrophobic amino acids. The hydrophobic amino acids are precursors of chocolate aroma (Misnawi et al., 2002).

Interestingly, pulp $\mathrm{pH}$ level of the treatment at $5 \mathrm{~kg}$ was significantly higher at $48-66$ hours than that of $1 \mathrm{~kg}$ treatment $(\mathrm{p}<0.05)$. It was possible that the mass structure at $5 \mathrm{~kg}$ fermentation allowed a better aeration for the growth of acetic acid bacteria which rapidly utilize lactic acids. On the other hand, the pulp pH level in $1 \mathrm{~kg}$ fermentation remained mostly low, suggesting accumulation of organic acids in the pulp instead the cotyledon. This explanation is supported by the elevated $\mathrm{pH}$ level in the cotyledon.

\section{Cotyledon Colors}

There are various approaches to evaluate a successful fermentation. The easiest technique might be observing the color development of cotyledon. Fresh cotyledon from Forastero type has a purple color which is brought by anthocyanin, a member of polyphenol group. Well fermented beans are attributed to brown color, while unfermented beans exhibit grayish and purple color (Camu et al., 2008; Sulaiman \& Yang, 2015). The number of grayish and full purple beans are regulated in the Indonesian National Standard, SNI 2323:2008/Amd1:2010 (BSN, 2010). The grayish and fully purple (on more than $50 \%$ of interior surface) beans are considered unfermented, while brown and partly purple (on less than $50 \%$ of interior surface) are classified as fermented. In the standard, the lowest grade 3 permits $20 \%$ of unfermented beans.

Treatments above $1 \mathrm{~kg}$ scale had successfully produced unfermented beans with proportion meets the standard for grade 3 . Neither grayish nor fully purple beans were present in the $40 \mathrm{~kg}$ fermentation, which meets the criteria of grade 1 . Lower scale fermentation at $5-15 \mathrm{~kg}$ resulted in the grayish and full purple beans that can be categorized into grade 2 . Fermentation at $2.5 \mathrm{~kg}$ produced beans at grade 3 , while fermentation at $1 \mathrm{~kg}$ produced beans that was out of the standard due to unfermented bean content exceeding $20 \%$ (Figure 4). In addition, fermentation at 1 and $2.5 \mathrm{~kg}$ had higher variance than that of higher scales. Non-fermention beans obtained by drying beans right after extraction from the pods were attributed with very high per-

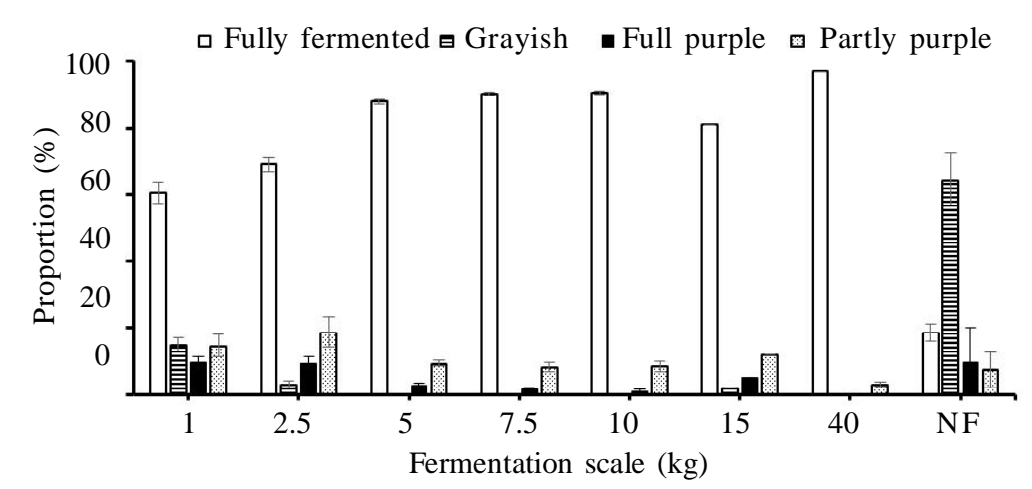

Figure 4. Analysis result of dried cocoa beans from fermentations at several different fermentation scales; $1,2.5,5,7.5,10,15,40 \mathrm{~kg}$ and non-fermentation (NF) beans. Parameter includes percentages of fully fermented, grayish, fully purple, and partly purple beans. Data are means of three replications. 
centage of grayish beans ( $>60 \%)$, besides some amount of purple beans.

During fermentation, cocoa beans lose viability due to exposure towards heat, ethanol and acetic acid that diffuse through testa. Ever since bean dies, the compartments inside the cell become disorganized, enabling anthocyanin to interact with respective enzyme, polyphenol oxidase. The enzyme oxidizes anthocyanin resulting insoluble material that has brown color (De Vuyst \& Leroy, 2020). It is hypothesized that in the fermentation lower than $40 \mathrm{~kg}$, the ethanol and acetic acid concentrations were limited. This has led to hindered disorganization event inside cotyledon cells, and consequently anthocyanin oxidation.

The quantity of wet beans moderately correlated with the percentage of grayish and purple beans. If the weight was plotted against percentage of grayish and purple beans, a logarithmic regression may apply $\left(\mathrm{R}^{2}=0.9557\right)$. The resulted equation is $\mathrm{y}$ $=-10.68 \ln (\mathrm{x})+23.157$, whereas $y$ is the percentage of unfermented (sum of grayish and full purple) beans, and $x$ is the weight of wet beans $(\mathrm{kg})$ (Figure 5). Using this equation, as low as $1.4 \mathrm{~kg}$ wet cocoa beans is required to result unfermented beans $19.6 \%$ which is permitted in the SNI standard grade 3. However, due to large variations occur in fermentations at 1 and $2.5 \mathrm{~kg}$, it is suggested to ferment not less than $5 \mathrm{~kg}$ of wet beans.

\section{Monitoring Fermentation}

Correlational analysis revealed that higher temperature at 42 hours was associated with lower amount of unfermented beans $(r>-0.8)$ (Table 1). Fermentations whose temperature at 42 hours were below $35^{\circ} \mathrm{C}$ had produced unfermented beans higher than $20 \%$. Temperature at 42 hours was also strongly correlated with the preceding temperature levels. Therefore, the temperature rise during anaerobic phase (642 hours) effectively predicts the development of unfermented beans. Initial temperature (0 hours) is not strongly correlated with temperature in the subsequent time points.

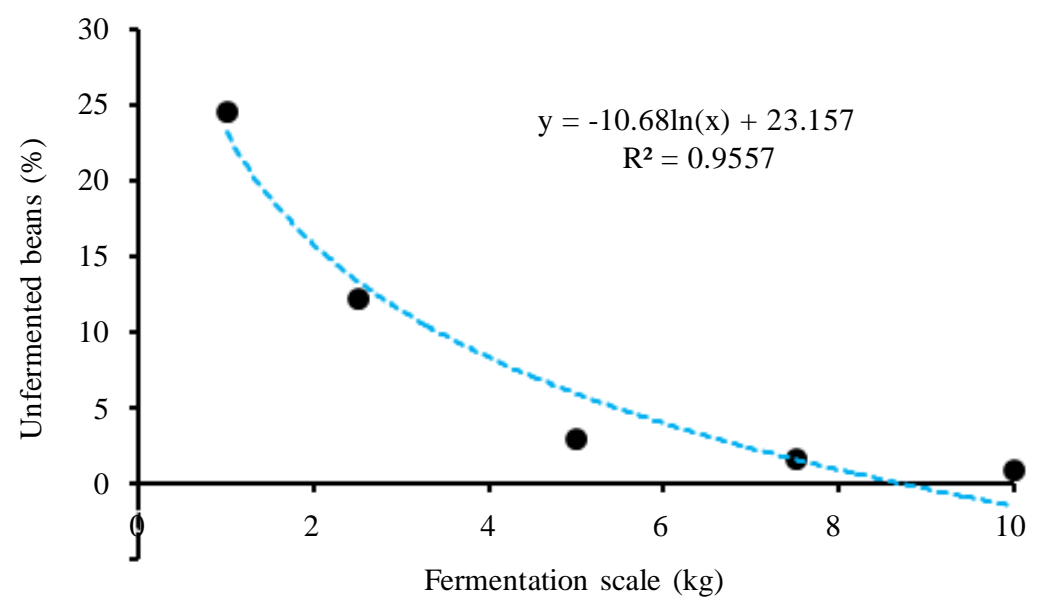

Figure 5. Relationship between percentage of unfermented beans and fermentation scales 
Table 1. Pearson's coefficient of correlation $(r)$ between bean color and temperature at several time points

\begin{tabular}{lcccc}
\hline Time point $(\mathrm{h})$ & Grayish & Partly purple & Full purple & $\begin{array}{c}\text { Unfermented } \\
\text { (grayish + full purple) }\end{array}$ \\
\hline 0 & -0.48 & -0.49 & -0.58 & -0.56 \\
6 & -0.45 & -0.58 & -0.57 & -0.54 \\
12 & -0.46 & -0.72 & -0.65 & -0.58 \\
16 & -0.49 & -0.73 & -0.67 & -0.60 \\
24 & -0.48 & -0.67 & -0.62 & -0.58 \\
30 & -0.6 & -0.84 & -0.81 & -0.74 \\
36 & -0.77 & -0.82 & -0.88 & -0.87 \\
42 & -0.82 & -0.74 & -0.87 & -0.90 \\
48 & -0.71 & -0.6 & -0.72 & -0.76 \\
54 & -0.62 & -0.81 & -0.84 & -0.76 \\
60 & -0.6 & -0.75 & -0.82 & -0.74 \\
66 & -0.59 & -0.63 & -0.76 & -0.71 \\
72 & -0.52 & -0.63 & -0.69 & -0.64 \\
78 & -0.5 & -0.68 & -0.72 & -0.63 \\
90 & -0.61 & -0.73 & -0.81 & -0.74 \\
96 & -0.58 & -0.74 & -0.81 & -0.72 \\
\end{tabular}

\section{CONCLUSIONS}

This study concludes that cocoa bean fermentation is accommodated by small amount of wet beans of less than $40 \mathrm{~kg}$. Fermentation at $5-15 \mathrm{~kg}$ and $2.5 \mathrm{~kg}$ produced beans that met criteria of SNI 2323:2008/ Amd1: 2010 grade 2 and 3, respectively. Only treatment of $40 \mathrm{~kg}$ scale is able to produce beans meeting the standard grade 1 . Fermentation monitoring can be carried out by observing the temperature of fermenting mass at the 42 hours, whereas temperature below $35^{\circ} \mathrm{C}$ is associated with higher percentage of unfermented beans.

\section{AUTHOR CONTRIBUTION}

Ariza Budi Tunjung Sari is the main author that was responsible for planning and conducting experiment, data analysis and manuscript preparation. Hendy Firmanto is the co-author contributing in the data analysis and interpretation. Teguh Wahyudi is co-author contributing in data interpretation and proofreading.

\section{ACKNOWLEDGEMENTS}

This study was funded by Directorate General of Estate Crop, Ministry of Agriculture, and Indonesian Coffee and Cocoa Research Institute. The authors thank Dr. Misnawi and Noor Ariefandie Febrianto for their kind and generous advice.

\section{REFERENCES}

Ardhana, M. M \& G. H. Fleet (2003). The microbial ecology of cocoa bean fermentations in Indonesia. International Journal of Food Microbiology, 86, 87-99.

Beg, M.S.; S. Ahmad; K. Jan \& K. Bashir (2017). Status, supply chain and processing of cocoa - A review. Trends in Food Science \& Technology, 66, 108-116.

BSN (2010). SNI 2323:2008/Amd1:2010 Biji Kakao. Badan Standardisasi Nasional. Jakarta.

Camu, N.; T. De Winter; S.K. Addo; J.S. Takrama; H. Bernaert \& L. De Vuyst (2008). Fermentation of cocoa beans: Influence of microbial activities and polyphenol concentrations on the flavour of chocolate. 
Journal of the Science of Food and Agriculture, 88, 2288-2297.

Deesuth, O.; P. Laopaiboon \& L. Laopaiboon (2016). High ethanol production under optimal aeration conditions and yeast composition in a very high gravity fermentation from sweet sorghum juice by Saccharomyces cerevisiae. Industrial Crops and Products, 92, 263-270.

de Vuyst, L. \& F. Leroy (2020). Functional role of yeasts, lactic acid bacteria and acetic acid bacteria in cocoa fermentation processes. FEMS Microbiology Review, 44, 432-453.

Fahrurrozi (2015). Microbiological and Byochemical Investigation of Cocoa Bean Fermentation Distribution. Department of Chemistry Faculting of Mathematics and Natural Sciences. University of Hamburg. Hamburg, Germany.

Lefeber, T.; W. Gobert; G. Vrancken ; N. Camu \& L. De Vuyst (2011). Dynamics and species diversity of communities of lactic acid bacteria and acetic acid bacteria during spontaneous cocoa bean fermentation in vessels. Food Microbiology, 28, 457-464.

Misnawi; J. Selamat; S. Nazamid \& B. Jamilah (2002). Activation of remaining key enzymes in dried under-fermented cocoa beans and its effect on aroma precursor formation. Food Chemistry, $78,407-417$.

Neilson, J. (2007). Global markets, farmers and the state: Sustaining profits in the indonesian cocoa sector. Bulletin of Indonesian Economic Studies, 43, 227-250.
Pelicaen, R.; D. Gonze; B. Teusink; L. De Vuyst \& S. Weckx (2019). Genome-scale metabolic reconstruction of Acetobacter pasteurianus $386 \mathrm{~B}$, a candidate functional starter culture for cocoa bean fermentation. Frontiers in Microbiology, $10,2801$.

Pereira, G.V.; K.T. Magalhães; E.G. de Almeida; I. da Silva Coelho \& R.F. Schwan (2013). Spontaneous cocoa bean fermentation carried out in a noveldesign stainless steel tank: Influence on the dynamics of microbial populations and physical-chemical properties. International Journal of Food Microbiology, 161, 121-133.

Raharto, S. (2016). Institutional development model cocoa farmers in Blitar Regency, East Java Provice. Agriculture and Agricultural Science Procedia, 9, 95-102.

Santosa, E., G.P. Sakti; M.Z. Fattah; S. Zaman; \& A. Wachjar (2018). Cocoa production stability in relation to changing rainfall and temperature in East Java, Indonesia. Journal of Tropical Crop Science, 5, 6-17.

Sulaiman, K.B. \& T.A. Yang (2015). Color characteristics of dried cocoa using shallow box fermentation technique. World Academy of Science, Engineering and Technology, 9, 1281-1285.

Tothmihaly, A.; S. von Cramon-Taubadel \& V. Ingram (2019). How can the environmental efficiency of Indonesian cocoa farms be increased?. Ecological Economic, 1(158), 134-145.

Yusianto (1990). Turning design optimation of bulk cocoa fermentation process. Pelita Perkebunan, 6, 63-69.

$* * 0 * *$ 
Sari et al. 